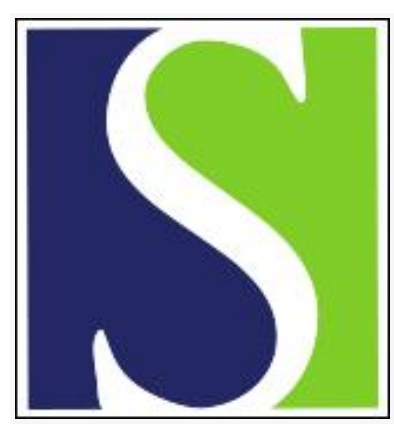

Scand J Work Environ Health 1994;20(1):42-47

https://doi.org/10.5271/sjweh.1430

Issue date: $01 \mathrm{Feb} 1994$

Non-Hodgkin's lymphoma and agricultural practices in the prairie provinces of Canada.

by Morrison HI, Semenciw RM, Wilkins K, Mao Y, Wigle DT

Affiliation: Bureau of Chronic Disease Epidemiology, Laboratory Centre for Disease Control, Health Canada, Ottawa.

This article in PubMed: www.ncbi.nlm.nih.gov/pubmed/8016598

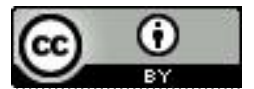




\title{
Non-Hodgkin's lymphoma and agricultural practices in the prairie provinces of Canada
}

\author{
by Howard I Morrison, PhD, Robert M Semenciw, MSc, Kathryn Wilkins, MSc, \\ Yang Mao, PhD, Donald T Wigle, MD ${ }^{1}$
}

\begin{abstract}
MORRISON HI, SEMENCIW RM, WILKINS K, MAO Y, WIGLE DT. Scand $J$ Work Environ Health 1994;20:42 - 7. OBJEctives - The aim of this study was to provide an update of a cohort study $(1971-1985)$ that previously reported a significant trend in the risk of non-Hodgkin's lymphoma among male Saskatchewan farm operators according to fuel-oil expenditures and herbicide spraying for farms less than 1000 acres (2570 hectares) by including two additional Canadian prairie provinces, two additional years of follow-up, and data from the 1981 Census of Agriculture. METHods - Information on farmers from 1971 records of the Census of Agriculture was linked to 1971 records of the Census of Population, to 1981 records of the Census of Agriculture, and to death records. Poisson regression was used to estimate risks according to herbicide spraying and fuel and oil expenditures. Results The addition of a further two years of follow-up resulted in lower risk estimates associated with herbicide spraying for Saskatchewan. No excess risk was observed between herbicide spraying and nonHodgkin's lymphoma for Alberta or Manitoba in the 1971 data. However, a significantly increased risk of non-Hodgkin's lymphoma according to acres sprayed with herbicides was observed for the three provinces combined when the herbicide spraying data from the 1981 Census of Agriculture was used $[\geq 380$ acres ( $\geq 939$ hectares) sprayed, rate ratio $2.11,95 \%$ confidence interval $1.1-3.9]$. Conclusions - Although the current results are not entirely consistent with the original Saskatchewan analysis, they support the overall finding of an association between herbicides and risk of fatal non-Hodgkins lymphoma. Prospective cohort studies are needed to overcome the limitations of existing epidemiologic studies.
\end{abstract}

Key terms: agricultural workers' diseases, cohort studies, herbicides, petroleum.

An increased risk of non-Hodgkin's lymphoma among farmers has been reported from the United States, Canada, Australia, and New Zealand (1-8). While several studies have noted an increased risk according to farm exposure to herbicides $(1,9-11)$, others have failed to observe such a relationship $(2,4)$.

A recent analysis of Saskatchewan farmers (9) noted an increased risk of non-Hodgkin's lymphoma mortality with fuel and oil expenditures and with increasing numbers of acres sprayed with herbicides on farms of less than 1000 acres (2570 hectares). Using data for all three Canadian prairie provinces and adding two years of follow-up plus additional census data, this report updates the study.

The Canadian farm operator study was established to examine the relation between various farm practices and specific cancers. In addition to the study of non-Hodgkin's lymphoma among Saskatchewan farmers (9), other papers have examined cancers of the brain (12), prostate (13), and multiple myeloma (14).

\footnotetext{
Bureau of Chronic Disease Epidemiology, Laboratory Centre for Disease Control, Health Canada, Ottawa, Canada.
}

Reprint requests to: Dr HI Morrison, Laboratory Centre for Disease Control, Ottawa, Ontario, Canada K1A AL2.

\section{Subjects and methods}

\section{Data sources}

The data sources used in this study are described in the original Saskatchewan paper (9). In brief, a cohort of male farm operators was assembled by Statistics Canada, and data from the 1971 Canadian censuses of agriculture and population were linked. The results were then linked to death records contained in the Canadian Mortality Data Base with the use of the Generalized Iterative Record Linkage System (15, 16). Death certificates were obtained by Statistics Canada for farmers whose underlying cause of death was recorded as non-Hodgkin's lymphoma. Occupation, as recorded on the death certificates, was used to remove probable false links resulting from the use of the computerized record linkage system.

After the preprocessing of the Central Farm Register and the linking of the agriculture and population censuses, records of 156242 male farm operators $(92.9 \%$ of all male farm operators active in 1971) from the Canadian prairie provinces of Manitoba, Saskatchewan, and Alberta were available for the mortality linkage. The results of this report are based on the mortality experience of farmers whose age was at least 35 years at some point during the follow-up period (June 1971 through December 1987). A total of 155547 men met this criterion.

In addition, the Agriculture Division of Statistics Canada provided a longitudinal file containing infor- 
mation on farming practices from the Census of $\mathrm{Ag}$ riculture from 1966, 1971, 1976, 1981, and 1986. It was created by merging data for each farm on the basis of location and the operator's surname. For this analysis, the age of the farm operator on each census was compared, and records were removed if the age of an operator, as given on successive census forms, did not increase by the expected five-year increment. For data for a farm operator from the 1981 Census of Agriculture to be included, the operator had to be alive and living on the same farm as at the time of the 1971 census. Data from the Census of Agriculture on the number of acres sprayed with herbicides and expenditures on fuel and oil applied to the year prior to the census (eg, the 1971 census data for these variables were based on the calendar year 1970).

Data on herbicide exposure were stratified into an unexposed category plus categories corresponding to Census of Agriculture-specific tertiles. Fuel and oil expenditures were stratified into census-specific quartiles, as an "unexposed" group was not available (almost all farmers reported some expenditure on fuel). Because of small numbers, quartiles two and three were combined in the cross-classified analysis.

\section{Statistical analysis}

Standardized mortality ratios (SMR) were calculated with the combined Manitoba, Saskatchewan, and Alberta male age-specific mortality rates as the reference, with confidence intervals based on the Poisson distribution (17).

Models were fitted to the grouped data with the use of Poisson regression analyses $(18,19)$. Farm practices were evaluated for confounding although none was known to be an independent risk factor. Models were constructed which included terms for age, calendar-year period, fuel-oil expenditures, and the number of acres sprayed with herbicides. Onedegree-of-freedom tests for trend in relative risk with increasing exposure were performed in which a continuous variable was added to a model containing the remaining terms, and the improvement in fit was assessed (18).

Because the original Saskatchewan analyses noted an increased risk of non-Hodgkin's lymphoma with increasing acres sprayed with herbicides for farms of less than 1000 acres ( 2570 hectares) only, models were also constructed in which only farmers of farms less than 1000 acres were included.

\section{Results}

\section{Mortality}

The mortality rates for major causes of death among the 155547 farm operators aged 35 years or more were significantly below those for men in the provinces as a whole, with an SMR for all-cause mortality of 0.72 . The observed number of deaths among the farm operators was also significantly lower than expected for non-Hodgkin's lymphoma (SMR $=0.79$, 95\% CI 0.69-0.89).

\section{Non-Hodgkin's lymphoma and farming practices}

Estimated relative risks of death due to non-Hodgkin's lymphoma according to acres sprayed with herbicides and fuel and oil expenditures in 1970 are displayed in table 1 for operators of Saskatchewan farms. A small, but not statistically significant, increased risk for acres sprayed with herbicides was

Table 1. Estimated relative risks and $95 \%$ confidence intervais from a Poisson regression analysis of non-Hodgkin's lymphoma mortality, Saskatchewan farmers, 1971-1987.

\begin{tabular}{|c|c|c|c|c|c|c|}
\hline \multirow{2}{*}{$\begin{array}{l}\text { Farming } \\
\text { practice }\end{array}$} & \multicolumn{3}{|c|}{ Farms $<1000$ acres $^{a}$} & \multicolumn{3}{|c|}{ All farms } \\
\hline & $\begin{array}{l}\text { Number } \\
\text { of deaths }\end{array}$ & $\begin{array}{l}\text { Relative } \\
\text { risk }^{b}\end{array}$ & $\begin{array}{c}95 \% \text { confidence } \\
\text { interval }\end{array}$ & $\begin{array}{l}\text { Number } \\
\text { of deaths }\end{array}$ & $\begin{array}{l}\text { Relative } \\
\text { risk }^{\mathrm{b}}\end{array}$ & $\begin{array}{c}95 \% \text { confidence } \\
\text { interval }\end{array}$ \\
\hline \multicolumn{7}{|c|}{$\begin{array}{l}\text { Acres sprayed with } \\
\text { herbicides, } 1970^{c}\end{array}$} \\
\hline $\begin{array}{l}0 \\
1-99 \\
100-249 \\
\geq 250\end{array}$ & $\begin{array}{l}41 \\
19 \\
29 \\
10\end{array}$ & $\begin{array}{l}1.0 \\
1.54 \\
1.45 \\
1.48\end{array}$ & $\begin{array}{l}0.89-2.65 \\
0.90-2.35 \\
0.73-3.00\end{array}$ & $\begin{array}{l}54 \\
19 \\
29 \\
15\end{array}$ & $\begin{array}{l}1.0 \\
1.34 \\
1.17 \\
0.95\end{array}$ & $\begin{array}{l}0.79-2.26 \\
0.74-1.85 \\
0.53-1.72\end{array}$ \\
\hline \multicolumn{7}{|c|}{$\begin{array}{l}\text { Canadian dollars spent } \\
\text { on fuel and oil for } \\
\text { farm purposes, } 1970^{d}\end{array}$} \\
\hline $\begin{array}{l}<360 \\
360-599 \\
600-899 \\
\geq 900\end{array}$ & $\begin{array}{l}17 \\
34 \\
31 \\
17\end{array}$ & $\begin{array}{l}1.0 \\
1.81 \\
2.27 \\
2.20\end{array}$ & $\begin{array}{l}1.00-3.27 \\
1.23-4.18 \\
1.09-4.42\end{array}$ & $\begin{array}{l}18 \\
34 \\
34 \\
31\end{array}$ & $\begin{array}{l}1.0 \\
1.71 \\
2.06 \\
2.05\end{array}$ & $\begin{array}{l}0.96-3.05 \\
1.14-3.72 \\
1.11-3.78\end{array}$ \\
\hline
\end{tabular}

a 1 acre $=0.405$ hectares.

b Model included terms for age, calendar period, acres sprayed with herbicides, and fuel and oil expenditures.

c Test for trend chi-square: farms $<1000$ acres $(1$ degree of freedom $)=1.97$, two-sided $P=0.16$; all farms $(1$ degree of freedom) $=0.00, P=1.00$

d Test for trend chi-square: farms $<1000$ acres ( 1 degree of freedom $)=5.24$, two-sided $P=0.02 ;$ all farms $(1 \mathrm{deg}$ ree of freedom) $=$ 4.61, two-sided $P=0.03$. 
restricted to farms of less than 1000 acres $(2570$ hectares), while an increased risk for fuel-oil expenditures did not vary by farm size. The lower limits of the confidence intervals for the top two quartiles of fuel and oil expenditures exceeded unity [rate ratios (RR) of 2.27 and 2.20], and the test for trend was statistically significant $(P=0.02)$. Although the test for trend for a model with herbicides alone was significant both without $\log$ transformation $(P=0.04)$ and with $\log$ transformation $(P=0.02)$, it was not significant after control for fuel and oil expenditures $(\mathrm{P}=0.16)$.

The estimated relative risks by acres sprayed with herbicides for all three prairie provinces combined were lower than for Saskatchewan alone (table 2).
In Manitoba, the risks were highest among the farmers reporting no herbicide use (table 3); no discernable pattern was observed in Alberta.

Use of the longitudinal file allowed assessment based on farm practices reported for 1980, as well as for 1970. For farm operators who lived on the same farm in both 1971 and 1981, according to 1980 farming practices with mortality follow-up from 1981 to 1987 , an increased risk of non-Hodgkin's lymphoma mortality associated with acreage sprayed with herbicides was observed for the prairies as a whole (table 4). The rate ratio for the highest quartile of 380 or more acres (939 or more hectares) sprayed was 2.11 (95\% CI 1.13-3.93). No difference in risk according to acres sprayed with herbicides was ob-

Table 2. Estimated relative risks and $95 \%$ confidence intervals from a Poisson regression analysis of non-Hodgkin's lymphoma mortality, Alberta, Saskatchewan and Manitoba farmers, 1971-1987.

\begin{tabular}{|c|c|c|c|c|c|c|}
\hline \multirow{2}{*}{$\begin{array}{l}\text { Farming } \\
\text { practice }\end{array}$} & \multicolumn{3}{|c|}{ Farms $<1000$ acres $^{a}$} & \multicolumn{3}{|c|}{ All farms } \\
\hline & $\begin{array}{l}\text { Number } \\
\text { of deaths }\end{array}$ & $\begin{array}{l}\text { Relative } \\
\text { risk }^{b}\end{array}$ & $\begin{array}{l}95 \% \text { confidence } \\
\text { interval }\end{array}$ & $\begin{array}{l}\text { Number } \\
\text { of deaths }\end{array}$ & $\begin{array}{l}\text { Relative } \\
\text { risk }^{\mathrm{b}}\end{array}$ & $\begin{array}{c}95 \% \text { confidence } \\
\text { interval }\end{array}$ \\
\hline \multicolumn{7}{|c|}{$\begin{array}{l}\text { Acres sprayed with } \\
\text { herbicides, } 1970^{c}\end{array}$} \\
\hline $\begin{array}{l}0 \\
1-99 \\
100-249 \\
\geq 250\end{array}$ & $\begin{array}{r}102 \\
40 \\
55 \\
18\end{array}$ & $\begin{array}{l}1.0 \\
1.19 \\
1.17 \\
1.03\end{array}$ & $\begin{array}{c}\cdot \\
0.83-1.72 \\
0.84-1.65 \\
0.61-1.73\end{array}$ & $\begin{array}{r}123 \\
40 \\
58 \\
32\end{array}$ & $\begin{array}{l}1.0 \\
1.10 \\
1.07 \\
0.92\end{array}$ & $\begin{array}{c}\cdot \\
0.77-1.57 \\
0.77-1.47 \\
0.61-1.39\end{array}$ \\
\hline \multicolumn{7}{|c|}{$\begin{array}{l}\text { Canadian doliars spent } \\
\text { on fuel and oil for } \\
\text { farm purposes, } 1970^{d}\end{array}$} \\
\hline $\begin{array}{l}<360 \\
360-599 \\
600-899 \\
\geq 900\end{array}$ & $\begin{array}{l}53 \\
68 \\
55 \\
39\end{array}$ & $\begin{array}{l}1.0 \\
1.40 \\
1.54 \\
1.56\end{array}$ & $\begin{array}{c}0.97-2.02 \\
1.04-2.28 \\
1.01-2.42\end{array}$ & $\begin{array}{l}55 \\
69 \\
60 \\
69\end{array}$ & $\begin{array}{l}1.0 \\
1.35 \\
1.43 \\
1.56\end{array}$ & $\begin{array}{c}\cdot \\
0.94-1.93 \\
0.98-2.08 \\
1.06-2.28\end{array}$ \\
\hline
\end{tabular}

Table 3. Estimated relative risks and $95 \%$ confidence intervals from a Poisson regression analysis of non-Hodgkin's lymphoma mortality, Alberta and Manitoba farmers, 1971-1987.

\begin{tabular}{|c|c|c|c|c|c|c|}
\hline \multirow{2}{*}{$\begin{array}{l}\text { Farming } \\
\text { practice }\end{array}$} & \multicolumn{3}{|c|}{ Manitoba } & \multicolumn{3}{|c|}{ Alberta } \\
\hline & $\begin{array}{l}\text { Number } \\
\text { of deaths }\end{array}$ & $\begin{array}{l}\text { Relative } \\
\text { risk }\end{array}$ & $\begin{array}{c}95 \% \text { confidence } \\
\text { interval }\end{array}$ & $\begin{array}{l}\text { Number } \\
\text { of deaths }\end{array}$ & $\begin{array}{l}\text { Relative } \\
\text { risk }\end{array}$ & $\begin{array}{c}95 \% \text { confidence } \\
\text { interval }\end{array}$ \\
\hline \multicolumn{7}{|c|}{$\begin{array}{l}\text { Acres sprayed with } \\
\text { herbicides, } 1970^{\mathrm{b}, c}\end{array}$} \\
\hline $\begin{array}{l}0 \\
1-99 \\
100-249 \\
\geq 250\end{array}$ & $\begin{array}{r}23 \\
6 \\
9 \\
7\end{array}$ & $\begin{array}{l}1.0 \\
0.59 \\
0.57 \\
0.62\end{array}$ & $\begin{array}{c}\cdot \\
0.24-1.46 \\
0.26-1.27 \\
0.24-1.56\end{array}$ & $\begin{array}{l}46 \\
15 \\
20 \\
10\end{array}$ & $\begin{array}{l}1.0 \\
1.22 \\
1.37 \\
1.13\end{array}$ & $\begin{array}{c}\cdot \\
0.68-2.19 \\
0.80-2.37 \\
0.54-2.35\end{array}$ \\
\hline \multicolumn{7}{|c|}{$\begin{array}{l}\text { Canadian dollars spent } \\
\text { on fuel and oil for } \\
\text { farm purposes, } 1970^{d}\end{array}$} \\
\hline $\begin{array}{l}<360 \\
360-599 \\
600-899 \\
\geq 900\end{array}$ & $\begin{array}{r}12 \\
11 \\
9 \\
13\end{array}$ & $\begin{array}{l}1.0 \\
1.40 \\
1.57 \\
2.24\end{array}$ & $\begin{array}{l}0.60-3.24 \\
0.63-3.88 \\
0.93-5.39\end{array}$ & $\begin{array}{l}25 \\
24 \\
17 \\
25\end{array}$ & $\begin{array}{l}1.0 \\
1.09 \\
0.90 \\
1.02\end{array}$ & $\begin{array}{l}0.62-1.93 \\
0.47-1.70 \\
0.56-1.87\end{array}$ \\
\hline
\end{tabular}

a 1 acre $=0.405$ hectares.

b Model included terms for age, calendar period, acres sprayed with herbicides, and fuel and oil expenditures.

c Test for trend chi-square: Alberta (1 degree of freedom) $=0.41$, two-sided $P=0.52 ; \mathrm{Manitoba}=1.35$, two-sided $P=0.25$.

d Test for trend chi-square: Alberta (1 degree of freedom) $=0.00$, two-sided $P=1.00 ;$ Manitoba $=3.12$, two-sided $P=0.08$ 
Table 4. Estimated relative risks and $95 \%$ confidence intervals from a Poisson regression analysis of non-Hodgkin's lymphoma mortality, restricted to farms appearing on both the 1971 and 1981 census of agriculture for Alberta, Saskatchewan and Manitoba farmers, $1981-1987$.

\begin{tabular}{|c|c|c|c|c|c|c|}
\hline \multirow{2}{*}{$\begin{array}{l}\text { Farming } \\
\text { practice }\end{array}$} & \multicolumn{3}{|c|}{ Farms $<1000$ acres $^{a}$} & \multicolumn{3}{|c|}{ All farms } \\
\hline & $\begin{array}{l}\text { Number } \\
\text { of deaths }\end{array}$ & $\begin{array}{l}\text { Relative } \\
\text { risk }^{b}\end{array}$ & $\begin{array}{c}95 \% \text { confidence } \\
\text { interval }\end{array}$ & $\begin{array}{l}\text { Number } \\
\text { of deaths }\end{array}$ & $\begin{array}{c}\text { Relative } \\
\text { risk }^{b}\end{array}$ & $\begin{array}{l}95 \% \text { confidence } \\
\text { interval }\end{array}$ \\
\hline \multicolumn{7}{|c|}{$\begin{array}{l}\text { Acres sprayed with } \\
\text { herbicides, } 1970^{c}\end{array}$} \\
\hline $\begin{array}{l}0 \\
1-159 \\
160-379 \\
\geq 380\end{array}$ & $\begin{array}{r}16 \\
9 \\
7 \\
13\end{array}$ & $\begin{array}{l}1.0 \\
1.26 \\
1.03 \\
2.13\end{array}$ & $\begin{array}{c}0.56-2.85 \\
0.42-2.50 \\
1.02-4.44\end{array}$ & $\begin{array}{r}21 \\
11 \\
8 \\
19\end{array}$ & $\begin{array}{l}1.0 \\
1.22 \\
0.87 \\
2.11\end{array}$ & $\begin{array}{c}. \\
0.59-2.52 \\
0.38-1.96 \\
1.13-3.93\end{array}$ \\
\hline \multicolumn{7}{|c|}{$\begin{array}{l}\text { Canadian dollars spent } \\
\text { on fuel and oil for } \\
\text { farm purposes, } 1980^{d}\end{array}$} \\
\hline $\begin{array}{l}<1800 \\
1800-2999 \\
3000-4999 \\
\geq 5000\end{array}$ & $\begin{array}{r}16 \\
14 \\
9 \\
6\end{array}$ & $\begin{array}{l}1.0 \\
1.27 \\
1.02 \\
1.41\end{array}$ & $\begin{array}{c}0.61-2.64 \\
0.44-2.36 \\
0.53-3.77\end{array}$ & $\begin{array}{l}17 \\
17 \\
14 \\
11\end{array}$ & $\begin{array}{l}1.0 \\
1.32 \\
1.08 \\
1.11\end{array}$ & $\begin{array}{l}0.67-2.61 \\
0.52-2.25 \\
0.50-2.47\end{array}$ \\
\hline
\end{tabular}

Table 5. Estimated relative risks and $95 \%$ confidence intervals from a Poisson regression analysis of non-Hodgkin's lymphoma mortality, restricted to farms appearing on both the 1971 and 1981 census of agriculture for Alberta, Saskatchewan and Manitoba farmers, $1981-1987$.

\begin{tabular}{|c|c|c|c|c|}
\hline $\begin{array}{l}\text { Farming } \\
\text { practice }\end{array}$ & & $\begin{array}{l}\text { Number } \\
\text { of deaths }\end{array}$ & $\begin{array}{l}\text { Relative } \\
\text { risk }\end{array}$ & $\begin{array}{l}95 \% \text { confidence } \\
\text { interval }\end{array}$ \\
\hline $\begin{array}{l}\text { Acres }^{a} \text { sprayed with } \\
\text { herbicides, } 1970\end{array}$ & $\begin{array}{l}\text { Acres }^{\text {a }} \text { sprayed with } \\
\text { herbicides, } 1980\end{array}$ & & & \\
\hline 0 & $\begin{array}{l}0 \\
1-379 \\
\geq 380\end{array}$ & $\begin{array}{r}10 \\
7 \\
8\end{array}$ & $\begin{array}{l}1.0 \\
1.01 \\
2.57\end{array}$ & $\begin{array}{c}0.38-2.64 \\
1.01-6.49\end{array}$ \\
\hline $1-249$ & $\begin{array}{l}0 \\
1-379 \\
\geq 380\end{array}$ & $\begin{array}{l}7 \\
9 \\
5\end{array}$ & $\begin{array}{l}1.04 \\
1.30 \\
1.63\end{array}$ & $\begin{array}{l}0.40-2.72 \\
0.53-3.19 \\
0.56-4.75\end{array}$ \\
\hline$\geq 250$ & $\begin{array}{l}0 \\
1-379 \\
\geq 380\end{array}$ & $\begin{array}{l}4 \\
3 \\
6\end{array}$ & $\begin{array}{l}1.59 \\
1.09 \\
2.95\end{array}$ & $\begin{array}{l}0.50-5.06 \\
0.30-3.89 \\
1.07-8.12\end{array}$ \\
\hline
\end{tabular}

a 1 acre $=0.405$ hectares.

served between farms with less than 1000 acres (2570 hectares) and all farms. Reduced rate ratios for fuel and oil expenditures were observed for the 1981 quartiles of expenditures as compared with those in 1970 (tables 2 and 4).

The rate ratio for farmers in the highest quartile of herbicide spraying for both 1970 and 1980 relative to those who reported no herbicide spraying in either 1970 or 1980 was 2.95 (95\% CI $1.07-8.12)$ (table 5).

\section{Discussion}

The overall death rates were significantly lower among the male farm operators than among the general male prairie population. A similar reduction was observed in the original Saskatchewan analysis (9).
It presumably reflects both the relatively low overall mortality among farmers previously noted in other studies (20), as well as a failure to identify correctly, with the use of the computerized linkage to the Canadian Mortality Data Base, all of the farmers who had died.

The previous analysis of Saskatchewan farmers noted a small, statistically nonsignificant deficit of deaths from non-Hodgkin's lymphoma (9). However, the present update based on data from all three prairie provinces noted a significant deficit, which reflected both low mortality from this cause among the cohort members in Manitoba and Alberta and increased statistical power.

The present study noted somewhat lower risks associated with herbicide spraying for Saskatchewan than those observed in the original analysis, in which mortality was followed only until the end of 1985 . 
This change may have been a chance finding, or it may reflect increasing exposure misclassification with longer follow-up. Rate ratios according to fuel and oil expenditures for Saskatchewan farmers were similar in both studies.

Inclusion of data from the additional two prairie provinces, in particular Manitoba, largely removed the positive relationship noted in the Saskatchewan analysis between herbicide spraying and non-Hodgkin's lymphoma mortality. There are the following two possibilities: either the original Saskatchewan findings or the present findings occurred due to chance or increased risks were restricted to Saskatchewan and, to a much less extent, Alberta. Phenoxy herbicide use, relative to other herbicide use, is more common in Saskatchewan than in Manitoba or Alberta (21). Among prairie farmers reporting phenoxy herbicide use, Saskatchewan farmers were the most likely to use 2,4-dichlorophenoxyacetic acid (2,4-D); the Manitoba farmers were the least likely (22). According to both the 1983 and 1984 national farm surveys, among prairie farm operators who had pesticides applied to their farm, those in Saskatchewan were the most likely to have applied the pesticides themselves, and Manitoba farmers were the least likely (Agriculture Division, Statistics Canada, unpublished data). However, any exposure-disease relationship in the present study between 2,4-D and non-Hodgkin's lymphoma must be inferred and must, at best, be considered tenuous; the census questionnaire asked about acres sprayed in 1970 with herbicides, not about exposure to 2,4-D.

Mortality from non-Hodgkin's lymphoma was significantly elevated among the farmers who reported spraying herbicides on $\geq 380$ acres ( $\geq 939$ hectares) in 1980. The magnitude of the risk was comparable to that observed in the original study. Unlike the original Saskatchewan analysis, an increased risk for farmers in the highest exposure category of herbicide exposure was not restricted to farms of less than 1000 acres (2570 hectares).

There is only limited evidence suggesting that phenoxy herbicides may be carcinogenic in animals. A statistically significant relationship between small intestinal adenocarcinoma in slaughtered sheep and exposure to phenoxy herbicides was noted in a New Zealand study (23). Companion dogs exposed in residential settings to 2,4-D were reported to be at an increased risk of developing malignant lymphomas (24). A statistically significant increase in astrocytomas was observed in male rats fed high doses of 2,4-D (25). However, several two-year animal bioassay studies have failed to note any carcinogenic effects (26).

Although an increased risk was observed in our study according to 1970 expenditures for fuel and oil, no significantly increased risk was observed according to 1980 expenditures. This finding may reflect an insufficiently long period of time between exposure and outcome, or it may indicate the changing nature of exposure. For example, enclosed tractor cabs became more common, providing greater protection from engine exhaust.

The major limitation of this study is the potential for exposure misclassification. However, by including data from the 1981 census, the present study has improved the exposure assessment over the earlier analysis of Saskatchewan farm operators (9).

Previous case-referent studies have been criticized because of the potential for bias resulting from the use of proxy respondents (27). This was not a concern with the present cohort study. The similarity of our current findings with those of most case-referent studies (28) suggests that recall bias is unlikely to have produced the positive herbicide exposure-response gradients observed in case-referent studies, and it underscores the value of cohort studies of herbicide-exposed workers.

\section{Acknowledgments}

We thank Ms M Fair, Ms D Jordan-Simpson, and Ms $C$ Poliquin of the Canadian Centre for Health Information, Statistics Canada, Mr R Bollman of the Agriculture Division of Statistics Canada, and the provincial vital statistics registrars of Alberta, Saskatchewan, and Manitoba.

\section{References}

1. Hoar SK, Blair A, Holmes FF, Boysen CD, Robel RJ, Hoover R, et al. Agricultural herbicide use and risk of lymphoma and soft-tissue sarcoma. JAMA 1986; 256:1141-7.

2. Pearce N. Phenoxy herbicides and non-Hodgkin's lymphoma in New Zealand: frequency and duration of herbicide use. Br J Ind Med 1989;46:143-4.

3. Cantor KP. Farming and mortality from non-Hodgkin's lymphoma: a case-control study. Int J Cancer 1982;29:239-47.

4. Pearce NE, Sheppard RA, Smith AH, Teague CA. Non-Hodgkin's lymphoma and farming: an expanded case-control study. Int J Cancer 1987;39:155-61.

5. Schumacher MC. Farming occupations and mortality from non-Hodgkin's lymphoma in Utah. J Occup Med 1985;27:580-4.

6. Buesching DP, Wollstadt L. Cancer mortality among farmers. JNCI 1984;72:503.

7. Brownson RC, Reif JS. A cancer registry-based study of occupational risk for lymphoma, multiple myeloma and leukaemia. Int J Epidemiol 1988;17:27-32.

8. Giles GG, Lickiss JN, Baikie MJ, Lowenthal RM, Panton J. Myeloproliferative and lymphoproliferative disorders in Tasmania, 1972 - 80: occupational and familial aspects. JNCI 1984;72:1233 40.

9. Wigle DT, Semenciw RM, Wilkins K, Ritter L, Riedal D, Morrison $\mathrm{H}$, et al. Mortality study of Canadian farm operators: non-Hodgkin's lymphoma mortality and agricultural practices in Saskatchewan. JNCI 1990;82: $575-82$.

10. Hoar Zahm S, Weisenburger DD, Babbitt PA, Saal RC, Vaught JB, Cantor KP, et al. A case-control study of non-Hodgkin's lymphoma and agricultural factors in eastern Nebraska. Am J Epidemiol 1988;128:901.

11. Hardell L, Eriksson M, Lenner P, Lundgren E. Malignant lymphoma and exposure to chemicals, espe- 
cially organic solvents, chlorophenols and phenoxy acids: a case-control study. Br J Cancer 1981;43:169. 76.

12. Morrison HI, Semenciw RM, Morison D, Magwood $\mathrm{S}$, Mao Y. Brain cancer and farming in western Canada. Neuroepidemiology 1992;11:267-76.

13. Morrison HI, Savitz D, Semenciw R, Hulka B, Mao Y, Morison D, Wigle D. Farming and prostate cancer mortality. Am J Epidemiol 1993;137:270-80.

14. Semenciw RM, Morrison HI, Riedel D, Wilkins K, Ritter L, Mao Y. Multiple myeloma mortality and agricultural practices in the prairie provinces of Canada. J Occup Med 1993;35:557-61.

15. Jordan-Simpson D, Fair ME, Poliquin C. Canadian farm operator study: methodology. Health Rep 1990;2: $141-55$.

16. Howe GR, Lindsay J. A generalized iterative record linkage computer system for use in medical followup studies. Comput Biomed Res 1981;14:327-40.

17. Breslow NE, Day NE. Statistical methods in cancer research; vol II (The design and analysis of cohort studies). Lyon: International Agency for Research on Cancer, 1988:82-118. (IARC scientific publication; no 82.)

18. Breslow NE, Day NE. Statistical methods in cancer research; vol II: (The design and analysis of cohort studies). Lyon: International Agency for Research on Cancer, 1988:120-76. (IARC scientific publication; no 82.)

19. Numerical Algorithms Group Ltd. The GLIM system, release 3.77. Oxford (United Kingdom): Numerical Algorithms Group Ltd, 1987.

20. Blair A, Malker H, Cantor KP, Burmeister L, Wiklund K. Cancer among farmers: a review. Scand J Work
Environ Health 1985;11:397-407.

21. Manitoba Department of Agriculture: Agricultural statistics: annual herbicide use surveys. Winnipeg: Manitoba Department of Agriculture, 1955-1986.

22. Stemeroff M, Groenewegen J, Krystynak R. The benefits of 2,4-D: an economic assessment. Can Farm Econ 1991;23:3-19.

23. Newell KW, Ross AD, Renner RM. Phenoxy and picolinic acid herbicides and small-intestinal adenocarcinoma in sheep. Lancet 1984;2:1301-5.

24. Hayes HM, Tarone RE, Cantor KP, Jessen CR, McCurnin DM, Richardson RC. Case-control study of canine malignant lymphoma: positive association with dog owner's use of 2,4-dichlorophenoxyacetic acid herbicides. JNCI 1991;83:1226-31.

25. Serota, DG. Combined toxicity and oncogenicity study in rats: 2,4-dichlorophenoxyacetic acid: final report. Vienna VA: Hazeiton Laboratories American Inc, 1986.

26. Bond GG, Bodner KM, Cook RR. Phenoxy herbicides and cancer: insufficient epidemiologic evidence for a causal relationship. Fundam Appl Toxicol 1989;12: $172-88$.

27. Johnson RA, Mandel JS, Gibson RW, Mandel JA, Bender AP, Gunderson PD, et al. Data on prior pesticide use collected from self- and proxy respondents. Epidemiology 1993;4:157-64.

28. Morrison HI, Wilkins K, Semenciw R, Mao Y, Wigle DT. A review of studies of herbicides and cancer. JNCI 1992;84:1866-74.

Received for publication: 17 May 1993 